\title{
Kornelia Bem-Koziel
}

Uniwersytet Ekonomiczny w Krakowie

\section{Korzyści z wprowadzenia zasad społecznej odpowiedzialności biznesu w przedsiębiorstwie}

Społeczna odpowiedzialność biznesu $(\mathrm{SOB})^{1}$, będąca jeszcze niedawno zupełnie nową ideą, staje się coraz częściej nieodzownym elementem strategii przedsiębiorstwa. Dostrzegły to już dawno przedsiębiorstwa amerykańskie, a zwłaszcza duże międzynarodowe korporacje. To one przyniosły ideę SOB do Polski. Firmy te zauważyły, że ze społeczną odpowiedzialnością biznesu wiąże się wiele korzyści zarówno dla otoczenia, jak i dla samego przedsiębiorstwa.

Niniejszy artykuł składa się z trzech części. Pierwsza część ma na celu przybliżenie idei oraz zasad CSR. Druga pokazuje, jakie korzyści wynikają ze stosowania zasad społecznej odpowiedzialności w przedsiębiorstwie. Trzecia, ostatnia, przedstawia, jak te korzyści są postrzegane przez polskich menedżerów, klientów oraz osoby związane z public relations.

\section{Istota SOB}

Sformułowano wiele definicji społecznej odpowiedzialności biznesu. Ewoluowały one wraz z rozwojem idei SOB i poprzez wzajemne oddziaływanie na siebie teorii i praktyki. Według Komisji Europejskiej ,bycie społecznie odpowiedzialnym oznacza nie tylko wypełnianie zobowiązań przewidzianych w prawie, ale dalece więcej - większe inwestycje w kapitał ludzki, środowisko i stosunki z akcjonariuszami" (Gasparski 2003).

Niektórzy autorzy przez angażowanie się w społeczną odpowiedzialność biznesu rozumieją takie działania, w których ,przedsiębiorstwa dobrowolnie uwzględniają aspekty społeczne i ekologiczne w swoich działaniach handlowych oraz w kontaktach ze swoimi interesariuszami" (Filek 2006, s. 4). Społeczna odpowiedzialność biznesu rozumiana jest także jako dodatkowe, wykraczające poza prawne wymagania, inicjatywy firmy na rzecz społeczeństwa oraz środowiska naturalnego (Sójka 2003).

Spełnienie wszystkich wymogów formalnych i prawnych to za mało, aby mówić o byciu społecznie odpowiedzialnym. Bycie odpowiedzialnym to dobrowolne zaangażowanie się przedsiębiorstwa w zwiększanie inwestycji w zasoby ludzkie, w ochronę środowiska i relacje z interesariuszami. Społeczna odpowiedzialność to przede wszystkim proces, w ramach którego przedsiębiorstwa zarządzają swoimi relacjami z interesariuszami mogącymi mieć faktyczny wpływ na ich powodzenie $\mathrm{w}$ działalności gospodarczej.

Przez interesariuszy rozumiemy grupy żywotnie zainteresowane działalnością firmy. Zgodnie z zasadami Okrąłego Stołu z Caux, interesariusze to: klienci, pracownicy, właściciele/inwestorzy, dostawcy, konkurenci, wspólnoty lokalne (Filek 2006). Inne określenie proponuje B. Rok. Według niego za interesariuszy firmy uważa się wszystkie grupy czy jednostki, które mogą

\footnotetext{
${ }^{1}$ Społeczna odpowiedzialność biznesu - z ang. Corporate Social Responsibility (CSR), w języku polskim w skrócie SOB.
} 
wpływać lub są pod wpływem działania przedsiębiorstwa za pośrednictwem jego produktów, strategii i procesów wytwórczych, systemów zarządzania i procedur (Rok 2004). Przy tak rozumianych wzajemnych powiązaniach między przedsiębiorstwem a interesariuszami, do grupy tych ostatnich można zaliczyć niemal wszystkich.

Według jednej z nowszych definicji, bo pochodzącej z 2005 r., społeczna odpowiedzialność jest ,zobowiązaniem biznesu do przyczyniania się do zrównoważonego rozwoju przy współpracy zatrudnionych, ich rodzin, lokalnych społeczności oraz całego społeczeństwa, zmierzającej do poprawy jakości życia, co służy zarówno biznesowi, jak i rozwojowi społecznemu" (Whot does Business...). Definicja ta zwraca uwagę na to, że w działania społecznie odpowiedzialne, oprócz firmy, angażują się również interesariusze, oraz że SOB służy, a więc niesie korzyści zarówno przedsiębiorstwu, jak i społeczeństwu.

\section{Korzyści ze stosowania zasad społecznej odpowiedzialności biznesu}

Jest oczywiste, że społeczna odpowiedzialność biznesu ma odbicie w działalności przedsiębiorstwa. Działanie zgodne z zasadami odpowiedzialnego biznesu przynosi przedsiębiorstwu korzyści, które „wzmacniają się w miarę upływu czasu” (Rok 2004). Korzyści płynące z działań społecznie odpowiedzialnych można podzielić na dwie grupy: korzyści dla firmy (korzyści wewnętrzne) oraz korzyści społeczne (korzyści zewnętrzne).

Korzyści, jakie osiaga firma społecznie odpowiedzialna, to przede wszystkim: wzrost zainteresowania inwestorów, zwiększanie lojalności konsumentów i interesariuszy, poprawa relacji ze społecznością i władzami lokalnymi, wzrost konkurencyjności, podnoszenie poziomu kultury organizacyjnej firmy, kształtowanie pozytywnego wizerunku firmy u pracowników, pozyskiwanie i utrzymywanie najlepszych pracowników.

Działania moralnie odpowiedzialne przekładają się na przejrzystość w zarządzaniu, poprawiają wizerunek firmy, a co za tym idzie - poprawiaja jej relacje z otoczeniem. Firmy działające zgodnie z zasadami SOB stają się bardziej wiarygodne dla społeczności lokalnej, klientów, pracowników, a także inwestorów. „Dla wielu inwestorów wiarygodność finansowa firmy jest uzależniona od jej wiarygodności społecznej” (Rok 2004). Firmy opierające działalność na zasadach SOB są postrzegane jako stabilniejsze, niosące mniejsze ryzyko i bardziej godne zaufania niż firmy niepodejmujące tego typu działań. Dzieje się tak, ponieważ te przedsiębiorstwa charakteryzują się większą przejrzystością działań ekonomicznych, ekologicznych i społecznych. Swobodny dostęp do informacji dotyczących organizacji poprawia jej wizerunek i reputację. Wszystko to przekłada się na większą zdolność przyciągania strategicznych inwestorów oraz kredytów (Bazzichi 2003).

Nagrodą dla firmy za działania zgodne z zasadą społecznej odpowiedzialności jest także wzrost zaufania klientów, co ma swoje odbicie w ich lojalności. „Wysoki poziom reputacji oznacza zazwyczaj wysoki poziom lojalności klientów, jest mnożnikiem wartości. Wskazuje on, że strumień dochodów firmy będzie zapewniony w przewidywalnej przyszłości” (Young 2005). Klient ufający, że produkt, który kupuje, jest zgodny z jego oczekiwaniami i tym, co o nim mówi firma (np. z reklama), bezpieczny, produkowany z poszanowaniem godności ludzkiej i środowiska, chętniej będzie do niego wracał, a także będzie skłonny zapłacić za niego więcej. Potwierdza to badanie przeprowadzone wśród konsumentów ${ }^{2}$. Oprócz budowania reputacji i lojalności społeczna odpowiedzialność pomaga w nawiązywaniu kontaktów z klientami, umożliwia wzajemny

\footnotetext{
${ }^{2}$ Pierwsze w Polsce kompleksowe badanie na temat postaw konsumentów oraz liderów opinii wobec idei społecznej odpowiedzialności biznesu, Komunikowanie na rzecz CSR, czyli społecznej odpowiedzialności biznesu. Fundacja Komunikacji Społecznej, Warszawa 2003. Raport dostępny m.in. na stronie www.filantropia.org.pl
} 
przepływ informacji o potrzebach i dostępnych rozwiązaniach techniczno-organizacyjnych. Te informacje przyczyniają się do lepszego dopasowania produktu do potrzeb klienta, dzięki temu firma jest w stanie wytworzyć produkt o największej użyteczności dla odbiorcy. Owocuje to satysfakcją klienta i pogłębia jego lojalność. Jednocześnie, dzięki wzajemnej współpracy, firma poprawia jakość swoich dostaw (Gryszka 2002).

Działania społecznie odpowiedzialne to także tworzenie wartości dla społeczeństwa. Przedsiębiorstwo jest częścią otoczenia, w którym działa. Społeczność lokalna i przedsiębiorstwo oddziałują na siebie nawzajem. Zadowolone społeczeństwo, w którym funkcjonuje przedsiębiorstwo, sprzyja jego rozwojowi. Firma może oddziaływać na społeczeństwo poprzez ustanawianie standardów działania i bezpośrednią z nim współpracę. Bez wzajemnie sobie sprzyjających zasad współpracy skutki dla obu stron mogą być niekorzystne. Społeczna odpowiedzialność pomaga wypracować relacje korzystne dla obu stron, co prowadzi do zrównoważonego rozwoju, korzystnego i dla firmy, i dla otoczenia (Gryszka 2002). Nowe standardy działania oparte na zasadach społecznej odpowiedzialności poprawiają relacje przedsiębiorstwa ze społecznością i władzami lokalnymi, co ułatwia firmie sprawne i bezkonfliktowe działanie. Dzięki reputacji i zaufaniu, jakie wypracowuje sobie przedsiębiorstwo, jest ono chętniej akceptowane jako członek społeczności, na trwale się w niej zakorzenia. Nie musi obawiać się bojkotu ze strony lokalnej społeczności lub sytuacji, że zacznie być postrzegane jako niewygodny „element krajobrazu”. Zmniejsza się tym samym poziom ryzyka związanego z niestabilnością sytuacji.

CSR pomaga również poprawić relacje z akcjonariuszami. Dopasowanie się przedsiębiorstwa do nowych warunków rynkowych owocuje lepszymi wynikami i skutkuje pozytywną oceną akcjonariuszy. Długoterminowe powiązania biznesowe między firmą a jej zewnętrznymi interesariuszami, opierające się na przejrzystej polityce obu zainteresowanych stron, gwarantują stabilność obrotów i długofalowość współpracy. Skutkuje to zwiększeniem wartości firmy i decyduje o jej stabilnym rozwoju, co z kolei jest konieczne do uzyskania akceptacji akcjonariuszy z jednej strony, a pracowników - z drugiej. Stabilność i obustronne wsparcie pomagają w dalszym rozwoju przedsiębiorstwa (Gryszka 2002).

Wprowadzenie zasad odpowiedzialnego biznesu to także jeden $\mathrm{z}$ atutów, dzięki którym firmy zdobywają przewagę konkurencyjną. Społeczna odpowiedzialność mobilizuje firmy do wprowadzania wydajniejszych i bardziej innowacyjnych technologii, które pozwalają na obniżanie kosztów produkcji. Dodatkowo konstruktywny dialog ze wszystkimi interesariuszami zwiększa zdolność przedsiębiorstwa do uczenia się i usprawniania własnej działalności, również w relacjach z podmiotami zewnętrznymi. Przyczynia się to do zwiększania przewagi konkurencyjnej (Bazzichi 2003).

Dzięki podejmowaniu wyzwań społecznej odpowiedzialności biznesu ma miejsce także podnoszenie poziomu ,kultury organizacyjnej firmy opartej na zaufaniu, odpowiedzialności i przejrzystości dla wszystkich zainteresowanych. Dzięki temu unika się kosztów »złego partnerstwa«" (Rok 2004). Nie zapominajmy, że zaufanie jest nieodzownym elementem biznesu. „Brak zaufania między uczestnikami wymiany stwarza konieczność zawierania umów o skomplikowanych warunkach i angażowania prawników, którym trzeba za to płacić, czyli zwiększają się koszty transakcji. Zaufanie redukuje w sposób istotny koszty transakcji, a więc ma pozytywny wpływ na efektywność sytemu gospodarczego"(Lewicka-Strzałecka 1999).

Duże znaczenie dla biznesu mają korzyści z poprawy wizerunku firmy w oczach pracowników i ich zaufania. Jest to tym istotniejsze, że - jak zauważa S. Young - coraz częściej ,więzy łączące pracownika z sukcesem jego firmy są bardziej natury moralnej niż ekonomicznej”(Young 2005) ${ }^{3}$.

${ }^{3} \mathrm{Z}$ taką sytuacją mamy do czynienia w momencie zaspokojenia przez pracownika podstawowych potrzeb, czyli przy stosunkowo wysokich zarobkach. 
Dzięki społecznej odpowiedzialności biznesu, znajdującej wyraz m.in. w kodeksach etycznych, programach społecznych czy dbałości o środowisko, pracownicy z większym uznaniem odnoszą się do funkcjonowania firmy. Są bardziej zadowoleni z pracy, jaką wykonują, widząc jej sens, są lepiej zmotywowani, utożsamiają swoje interesy z interesami firmy. Dodatkowo przedsiębiorstwa społecznie odpowiedzialne częściej inwestują w kształcenie personelu. Taka inwestycja, oprócz satysfakcji, jaką daje pracownikowi, pozwala przedsiębiorstwu na dysponowanie wykwalifikowanymi i kompetentnymi pracownikami. Dokształcanie personelu to także możliwość pozytywnego motywowania pracownika (Bazzichi 2003). Dzięki takim działaniom pracownicy stają się integralną częścią przedsiębiorstwa, a ich praca jest bardziej wydajna. Wydajny pracownik jest nieodzownym ,warunkiem sukcesu, produkuje towary i usługi wysokiej jakości po najkorzystniejszych kosztach" (Young 2005).

Etycznej firmie łatwiej też pozyskać i utrzymać najlepszych pracowników. Nie zapominajmy, że oprócz wynagrodzenia finansowego ważne są cel pracy i płynąca z niej satysfakcja (która coraz częściej zaczyna brać górę). Rola satysfakcji z wykonywanej pracy staje się coraz ważniejsza wraz ze wzrostem zarobków. Praca jest istotną częścią życia każdego człowieka, a nie ma nic gorszego niż praca, która nie daje satysfakcji.

Na SOB zyskuje również otoczenie biznesu. Do korzyści, jakie osiąga społeczeństwo, można zaliczyć: nagłośnienie i rozwiązywanie istotnych problemów społecznych, edukowanie społeczeństwa, poprawę stanu środowiska przyrodniczego, dostęp do informacji o firmie, poszanowanie praw człowieka. „Firmy, wspierając i inicjując kampanie czy programy społeczne, przyczyniają się do nagłośnienia danego problemu, wzmocnienia postaw obywatelskich, zmniejszenia skali problemu czy nawet jego rozwiązania" (Rok 2004). Swoimi działaniami dają także przykład, jak należy postępować, występując w roli nauczyciela postaw moralnych.

Z SOB czerpie korzyści zarówno państwo, jak i społeczeństwo. Przedsiębiorstwa działające zgodnie z zasadą społecznej odpowiedzialności rzetelniej wywiązują się z płacenia wszelakiego rodzaju podatków. Dzięki temu do budżetu państwa wpływa większy strumień pieniędzy, których część może zostać przeznaczona na wydatki związane z potrzebami całego społeczeństwa.

\section{Postrzeganie korzyści z SOB w Polsce}

Potwierdzeniem istnienia korzyści ze społecznej odpowiedzialności biznesu są opinie polskich menedżerów, osób zajmujących się public relations i konsumentów. Nie podejmuję się oceny postrzegania SOB w Polsce. Zamierzam przedstawić korzyści postrzegane przez różne grupy interesariuszy.

Większość badanych polskich menedżerów wiąże działania SOB z korzyściami dla firmy ${ }^{4}$. Korzyści zostały podzielone na korzyści wewnętrzne, dotyczące bezpośrednio działalności firmy, oraz korzyści zewnętrzne, dotyczące otoczenia, w jakim działa przedsiębiorstwo.

\footnotetext{
${ }^{4}$ Wykorzystane dane pochodzą $\mathrm{z}$ dwóch raportów: Menedżerowie 500 i odpowiedzialny biznes: wiedza - postawy - praktyka, Raport Forum Odpowiedzialnego Biznesu opracowany we współpracy z Bankiem Światowym i Akademią Rozwoju Filantropii, Warszawa 2003; What Does Business Think about Corporate Social Responsibility? Part II: A Comparison of Attitudes and Practices in Hungary, Poland and Slovakia, Enabling a Better Environment for CSR in CEE Countries Project, raport z 2005 r. Dane z obydwu raportów nieco się od siebie różnią, różniły się bowiem pytania, dlatego porównanie wyników tych badań nie jest w pełni możliwe i daje obraz przybliżony.
} 
Za najważniejsze korzyści wewnętrzne zaangażowania społecznego biznesu menedżerowie biorący udział w obydwu analizowanych badaniach uważają:

- przetrwanie biznesu i pozyskanie przewagi konkurencyjnej,

- pozyskanie i utrzymanie najlepszych pracowników, a także wzrost ich motywacji,

- bardziej skrupulatne przestrzeganie przepisów prawa,

- zmniejszenie kosztów,

- łatwiejszy dostęp do kapitału.

Jako ważne korzyści menedżerowie wymieniają także: podnoszenie kultury organizacji, doskonalenie jakości zarządzania, wzrost produkcji, jakości i sprzedaży. W nowszym badaniu duża grupa menedżerów do korzyści płynących ze stosowania SOB zalicza przede wszystkim przetrwanie biznesu i wzrost jego konkurencyjności. Nie było to tak widoczne w badaniu z $2003 \mathrm{r}$. Może to świadczyć o zmianie sposobu myślenia polskich menedżerów, którzy zaczynają dostrzegać potrzebę funkcjonowania biznesu w odległej perspektywie. Wyniki wykorzystanych badań pokazują ryc. 1 i 2 .

Ryc. 1. Korzyści wewnętrzne z działań społecznie odpowiedzialnych według menedżerów - badanie z 2003 r.

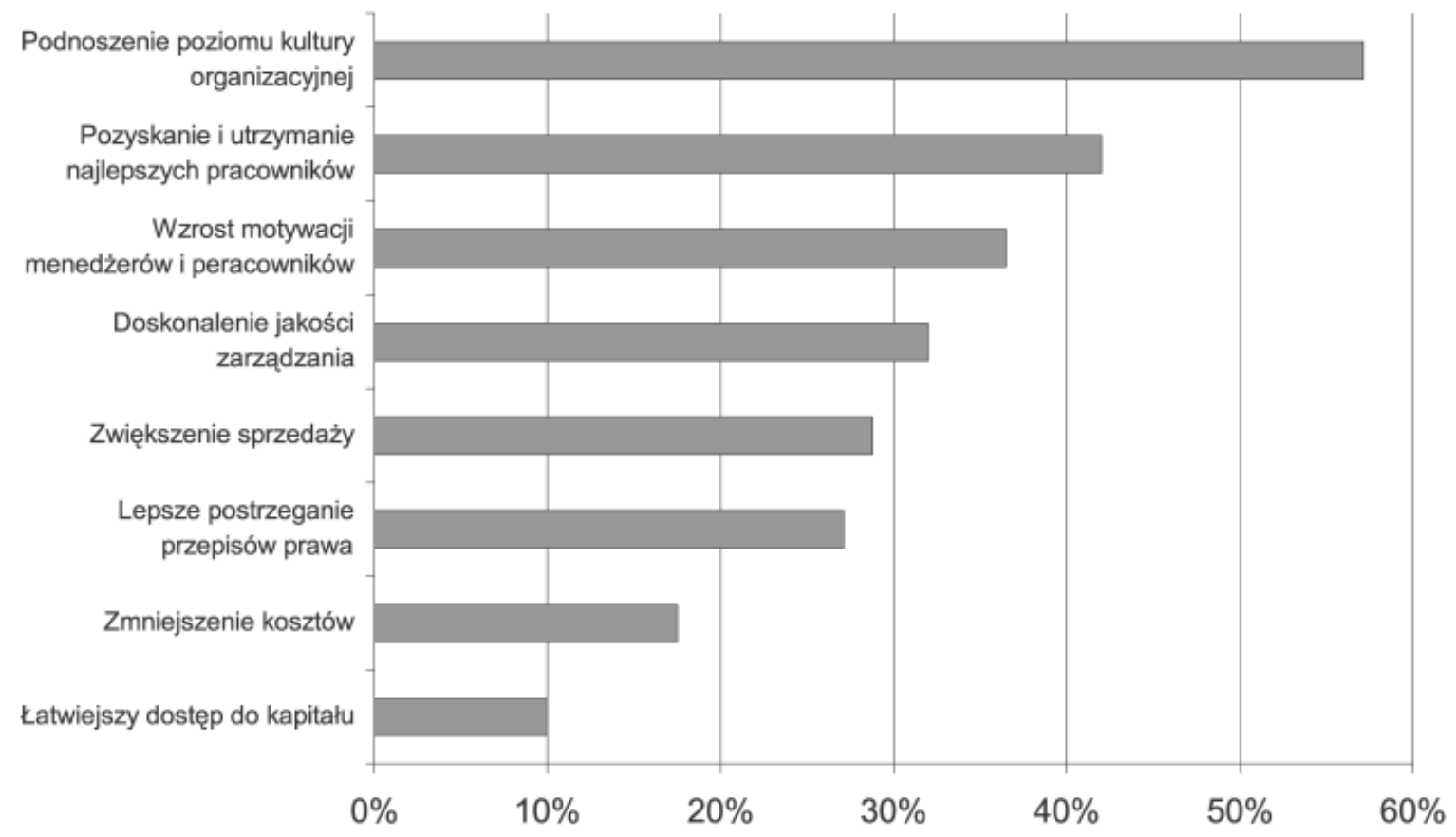

Źródło: Menedżerowie 500 i odpowiedzialny biznes: wiedza - postawy - praktyka, Raport Forum Odpowiedzialnego Biznesu opracowany we współpracy z Bankiem Światowym i Akademią Rozwoju Filantropii, Warszawa 2003. 
Ryc. 2. Korzyści wewnętrzne z działań społecznie odpowiedzialnych według menedżerów - badanie z 2005 r.

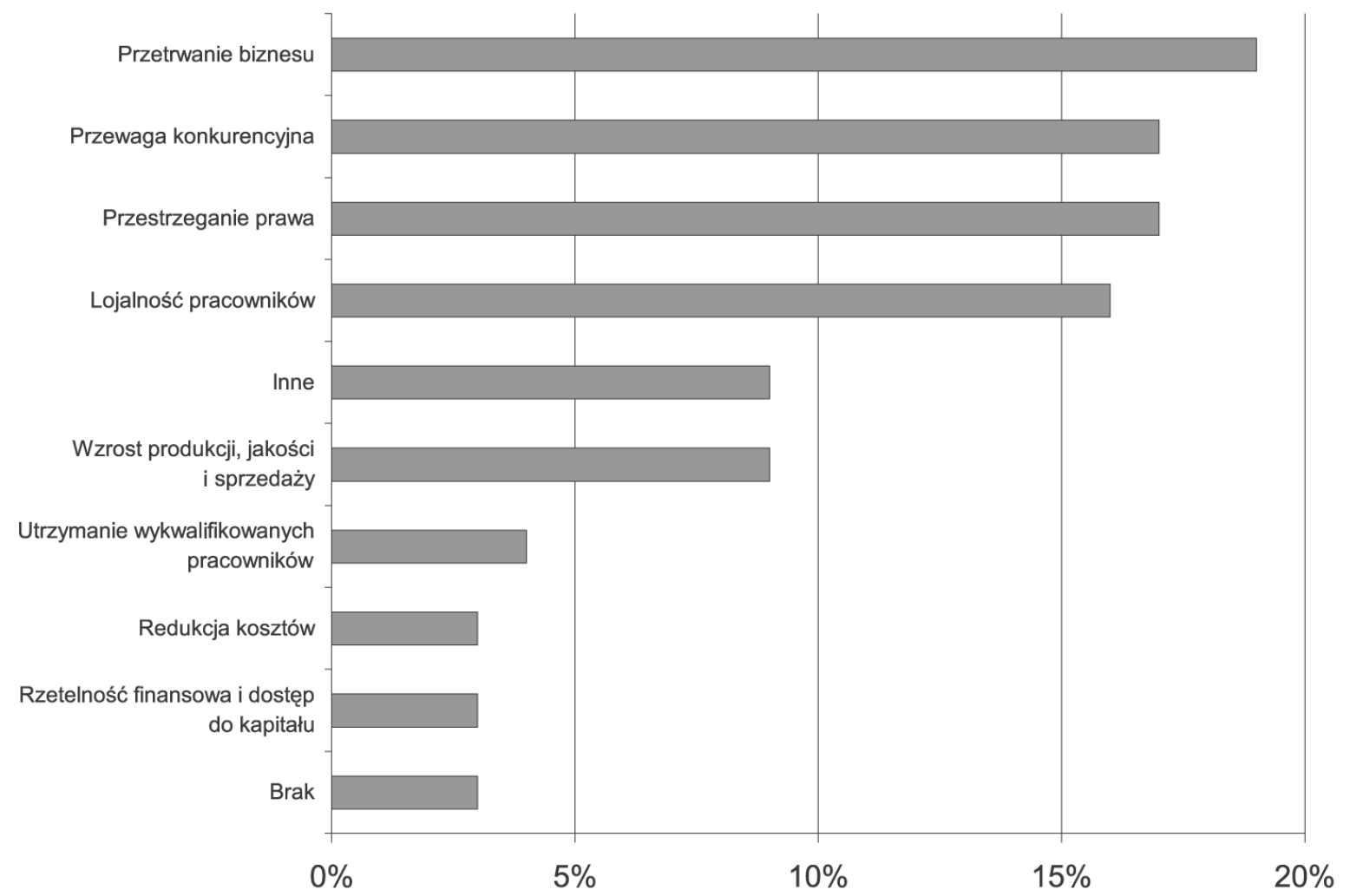

Źródło: What Does Business Think about Corporate Social Responsibility? Part II: A Comparison of Attitudes and Practices in Hungary, Poland and Slovakia, Enabling a Better Environment for CSR in CEE Countries Project.

W obydwu badaniach do korzyści zewnętrznych menedżerowie zaliczają przede wszystkim:

- nagłośnienie i rozwiązywanie istotnych problemów społecznych,

- edukowanie społeczeństwa,

- poprawę stanu środowiska przyrodniczego,

- dostęp do informacji o firmie,

- poszanowanie praw człowieka.

Za najważniejszą korzyść z działań społecznie odpowiedzialnych menedżerowie uważają poprawę reputacji firmy. Przekonanie to w ostatnich latach nie uległo zmianie. Poprawę reputacji uważano za najważniejszą korzyść zarówno w 2003 r., jak i 2005 r. Spośród korzyści wewnętrznych, jakie niesie wdrażanie zasad SOB, w obydwu badaniach wskazywane były: zwiększenie lojalności klientów, poprawa relacji ze społecznością lokalną, zrównoważony rozwój kraju, a także zwiększenie wpływów politycznych. W badaniu z 2005 r. w korzyściach uwzględniono również po raz pierwszy ochronę środowiska. Zmieniła się też hierarchia ważności poszczególnych korzyści. Postrzeganie przez menedżerów korzyści z praktyk odpowiedzialności społecznej biznesu i ich istotności w latach 2003 i 2005 przedstawiają ryc. 3 i 4. 
Ryc. 3. Korzyści zewnętrzne z działań społecznie odpowiedzialnych według menedżerów - badanie z 2003 r.

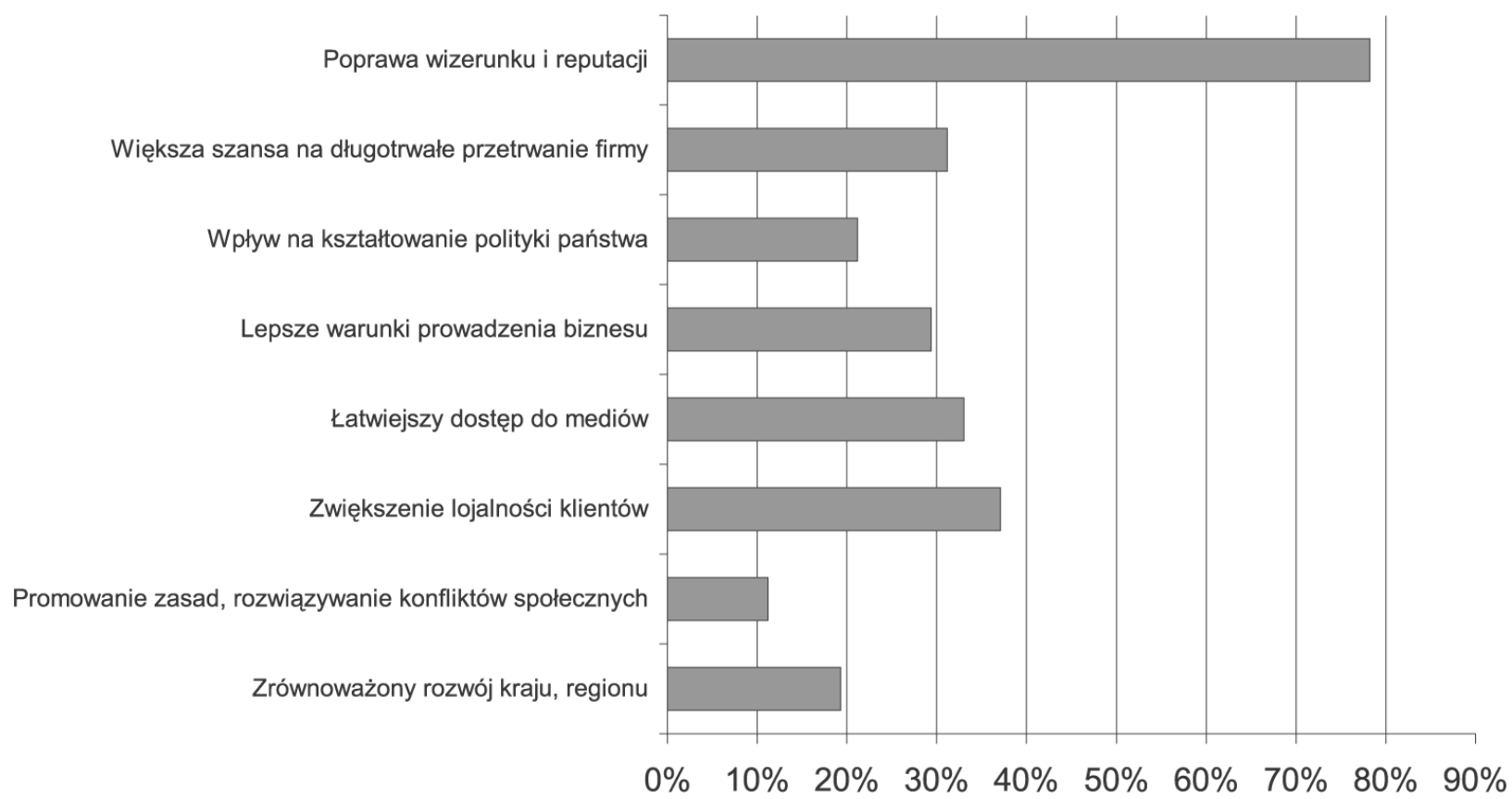

Źródło: Menedżerowie 500 i odpowiedzialny biznes: wiedza - postawy - praktyka, Raport Forum Odpowiedzialnego Biznesu opracowany we współpracy z Bankiem Światowym i Akademią Rozwoju Filantropii, Warszawa 2003, s. 6.

Ryc. 4. Korzyści zewnętrzne z działań społecznie odpowiedzialnych według menedżerów - badanie z 2005 r.

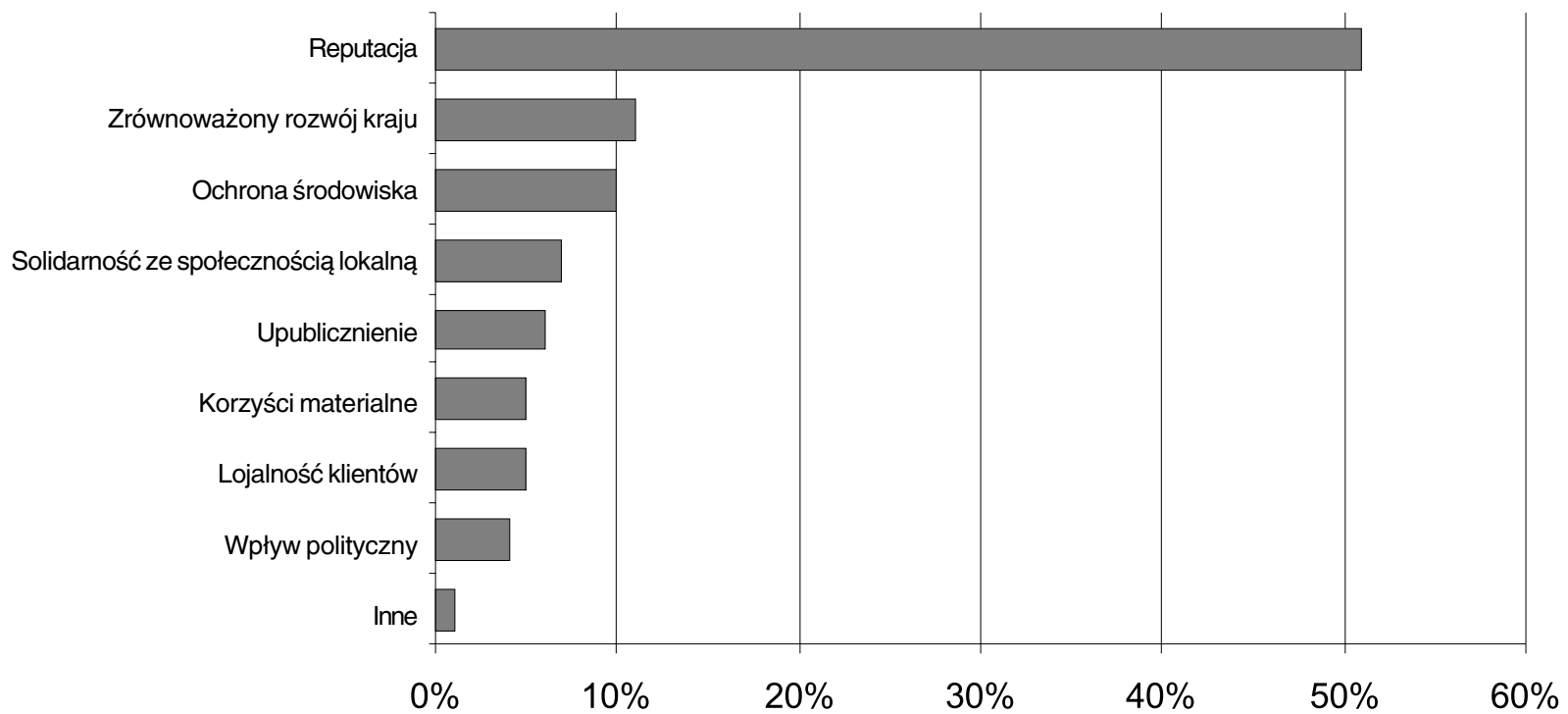

Źródło: What Does Business Think about Corporate Social Responsibility? Part II: A Comparison of Attitudes and Practices in Hungary, Poland and Slovakia, Enabling a Better Environment for CSR in CEE Countries Project. 
Przedstawione badania potwierdzają istnienie wcześniej wymienionych korzyści. Jak widać, polscy menedżerowie zauważają, że ze społeczną odpowiedzialnością biznesu wiąże się wiele powiązanych ze sobą korzyści.

Większość korzyści, jakie niesie ze sobą SOB, trudno zmierzyć, mają one jednak odbicie w wartości rynkowej firmy. Dlatego można spróbować zmierzyć opłacalność działań społecznie odpowiedzialnych poprzez takie wskaźniki, jak: wartość przychodów ze sprzedaży na 1 pracownika, zysk brutto na 1 pracownika, wskaźnik płynności bieżącej. Dotychczas w Polsce przeprowadzono jedno tego typu badanie ${ }^{5}$. Potwierdziło ono, że SOB niesie ze sobą wymierne korzyści i zwiększa efektywność działania przedsiębiorstwa. Firmy stosujące zasady społecznej odpowiedzialności mają znacznie większą płynność bieżącą ${ }^{6}$, a co za tym idzie - mają środki na terminowe regulowanie płatności, oszczędniej wykorzystują majątek trwały, który jest wielokrotnie bardziej rentowny niż w innych przedsiębiorstwach, również ich przychody ze sprzedaży są bardziej rentowne. Rentowność majątku trwałego w 2004 r. w grupie przedsiębiorstw stosujących zasady SOB wynosiła 92,4\%, w pozostałych przedsiębiorstwach - 24,3\%, a rentowność sprzedaży wynosiła odpowiednio 6,78\% i 5,97\%. Tak wysoka rentowność może świadczyć o oszczędniejszym wykorzystywaniu majątku trwałego, a więc o lepszym nim gospodarowaniu. Przytoczone dane potwierdzają opinie menedżerów o korzyściach płynących z działań społecznie odpowiedzialnych.

Badanie wykazało, że firmy społecznie odpowiedzialne opierają działalność na kapitale ludzkim, w który więcej inwestują niż pozostałe firmy i potrafią go lepiej wykorzystać. W 2004 r. średnie nakłady inwestycyjne na 1 pracownika zatrudnionego $\mathrm{w}$ przedsiębiorstwie stosującym zasady SOB były wyższe o $530 \mathrm{zł} \mathrm{niż} \mathrm{w} \mathrm{pozostałych} \mathrm{przedsiębiorstwach,} \mathrm{a} \mathrm{zysk} \mathrm{brutto} \mathrm{na} 1$ pracownika w pierwszej grupie przedsiębiorstw był znacznie wyższy i wyniósł 29,3 tys. zł rocznie w stosunku do 24,0 tys. zł. rocznie w pozostałych przedsiębiorstwach. Wszystkie mierniki związane z kapitałem ludzkim kształtują się korzystniej w grupie przedsiębiorstw społecznie odpowiedzialnych niż w grupie pozostałych przedsiębiorstw. Zarobki w przedsiębiorstwach społecznie odpowiedzialnych w 2004 r. były wyższe o 558 zł niż w pozostałych firmach ${ }^{7}$.

Jak pokazuje badanie, korzyści z SOB czerpie również państwo, ponieważ firmy społecznie odpowiedzialne płacą więcej na ubezpieczenia i świadczenia społeczne, są także znacznie bardziej efektywne podatkowo. Przedsiębiorstwa te generują więcej podatku VAT i podatków dochodowych, wpłacają też więcej na świadczenia społeczne.

Podsumowując, do korzyści ekonomicznych płynących ze stosowania zasad SOB można zaliczyć: lepszą płynność bieżąca, większą rentowność majątku, lepsze wykorzystanie kapitału ludzkiego, wyższą rentowność sprzedaży, większe inwestycje na 1 pracownika. Stosowanie SOB przynosi również korzyści pracownikom - w postaci wyższych wynagrodzeń i częstszych szkoleń, a państwu - większe przychody z tytułu ubezpieczenia i świadczeń społecznych oraz wpływów podatkowych.

\footnotetext{
${ }^{5}$ Bąk M., Bednarz P., Kulawczuk P., Rataj R., Szczęśniak A., Zając P., Analiza korzyści ze stosowania zasad spolecznej odpowiedzialności biznesu (CSR) w polskich przedsiębiorstwach. Streszczenie i wnioski, Fundacja „Instytut Badań nad Demokracją i Przedsiębiorstwem Prywatnym”, badanie dostępne na stronie fundacji: http://www.iped.pl/publikacje.php

${ }^{6}$ Wskaźnik płynności bieżącej w przedsiębiorstwach stosujących zasady SOB wyniósł 2,13, a w pozostałych przedsiębiorstwach - 1,16.

${ }^{7} \mathrm{~W} 2004$ r. średnie miesięczne wynagrodzenie brutto w grupie przedsiębiorstw stosujących zasady SOB wyniosło 2834 zl, a w pozostałych przedsiębiorstwach - 2276 zł.
} 
Również pracownicy public relations wiążą działania społecznie odpowiedzialne z korzyściami dla firmy. Za najważniejszą korzyść uważają poprawę reputacji i wizerunku firmy (79,07\% ankietowanych), a także wzmocnienie identyfikacji pracowników z firmą (ponad 47\%). Jako ważną korzyść wymieniają zrównoważony rozwój kraju i otoczenia firmy (Co PR-owcy..., 2007). Szczegółowe dane przedstawia ryc. 5.

Ryc. 5. Najważniejsze korzyści z prowadzenia działań SOB - według PR-owców

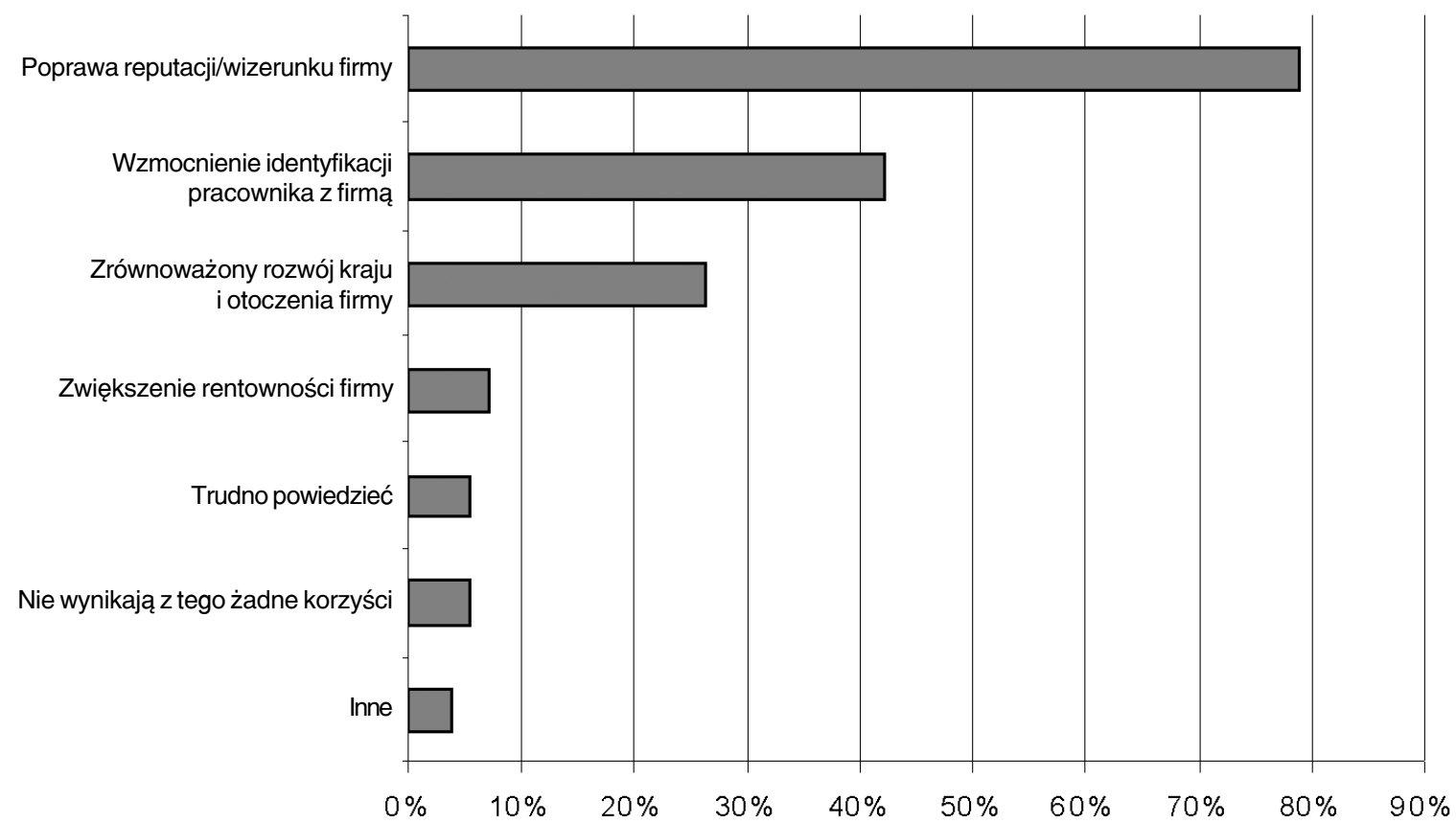

Źródło: Co PR-owcy myślą o CSR? Raport z badania na temat postaw PR-owców wobec idei CSR przeprowadzonego przez Forum Odpowiedzialnego Biznesu i Polskie Stowarzyszenie Public Relations [w:] Raport Odpowiedzialny biznes w Polsce w 2006 roku. Dobre praktyki, Forum Odpowiedzialnego Biznesu; Warszawa 2007, s. 12-14.

Potwierdzeniem korzyści płynących z działań SOB jest także opinia klientów. Spośród badanej grupy 30\% klientów deklaruje, że zdecydowałoby się na zakup wyrobów lub usług firmy, o której działalności uzyskali oni pozytywne informacje, a 17\% byłoby bardziej skłonnych do używania jej produktów w przyszłości. Usłyszane pozytywne informacje o firmie motywują aż $40 \%$ klientów do podjęcia z innymi osobami dyskusji o produktach i działalności przedsiębiorstwa. Jest to istotne, ponieważ 76\% ankietowanych deklaruje, że informacje i opinie o firmie czerpie właśnie z rozmów z innymi ludźmi ${ }^{8}$. Przy wyrażeniu opinii na temat firmy konsumenci najwięcej uwagi zwracają na jakość wyrobów i usług, traktowanie pracowników i dostawców, jakość obsługi. Czynniki wpływające na kształtowanie opinii konsumentów przedstawia ryc. 6.

Prawie 76\% ankietowanych przyznaje, że wolałoby kupować od firmy odpowiedzialnej społecznie, a 67,3 \% - że byliby bardziej skłonni zapłacić więcej za produkt, gdyby wiedzieli, że jest on przyjazny dla środowiska. Potwierdza to, jak ważne dla firmy są: budowanie dobrego wizerunku oraz dbałość o jakość produktu i dobre stosunki z interesariuszami.

\footnotetext{
${ }^{8}$ Dane pochodzą z Pierwszego w Polsce kompleksowego badania... op. cit.
} 
Ryc. 6. Czynniki decydujące o opinii konsumentów na temat firmy

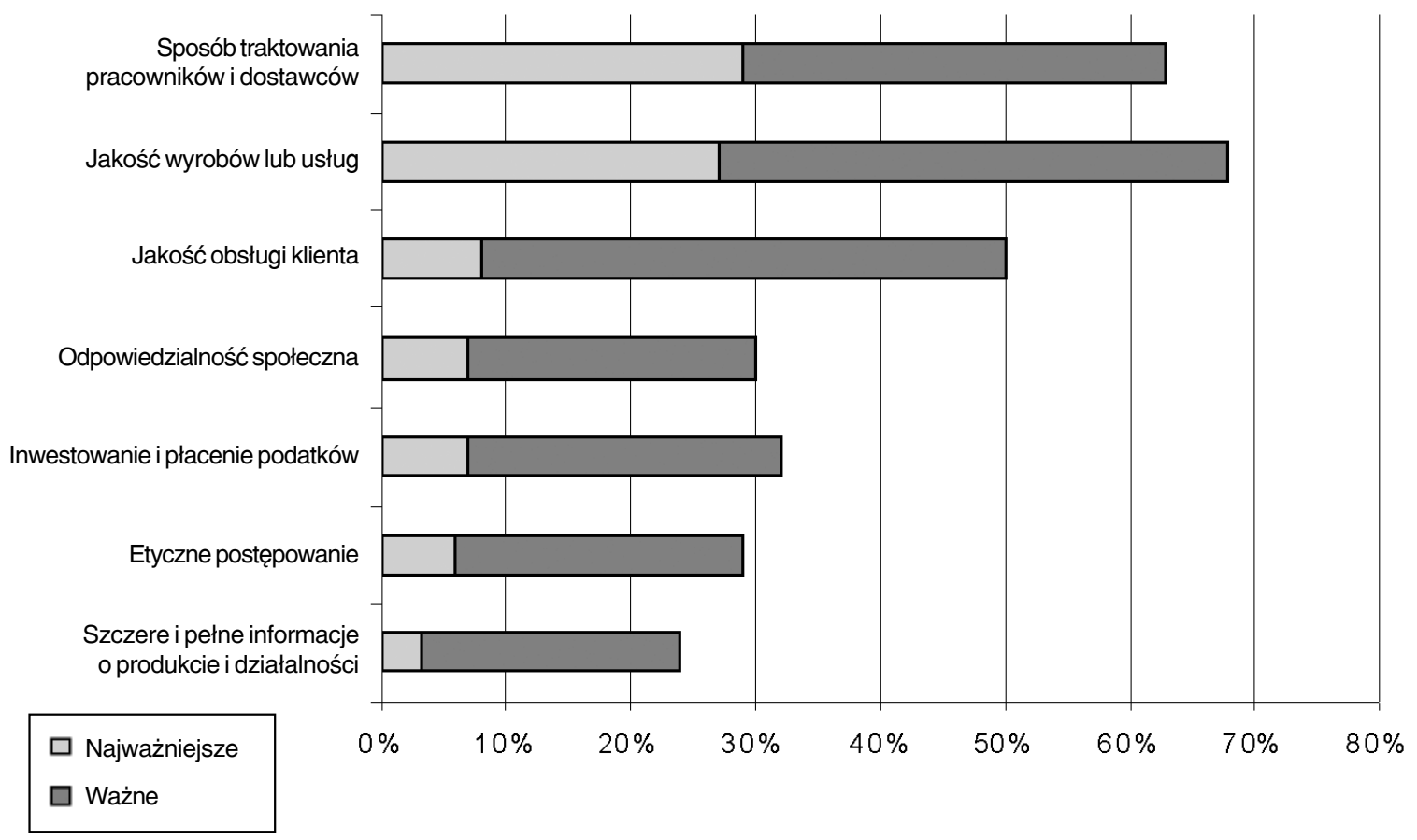

Źródło: Pierwsze w Polsce kompleksowe badanie na temat postaw konsumentów oraz liderów opinii wobec idei społecznej odpowiedzialności biznesu, Komunikowanie na rzecz CSR, czyli społecznej odpowiedzialności biznesu, Fundacja Komunikacji Społecznej, Warszawa 2003, s. 3.

Z działaniami SOB niewątpliwie wiąże się wiele korzyści. Część z nich ma odbicie w mierzalnych wskaźnikach ekonomicznych, część, jak zadowolenie klienta, pracownika i społeczeństwa, trudno zmierzyć, co nie znaczy, że są one mniej istotne. Dlatego każde przedsiębiorstwo patrzące w przyszłość i dążące do wpisania się na stałe w krajobraz gospodarczy powinno przy tworzeniu swojej strategii uwzględnić działania społecznie odpowiedzialne. Tym bardziej, że SOB przyczynia się do wzrostu konkurencyjności i do poprawy relacji przedsiębiorstwa ze zmieniającym się otoczeniem. SOB jest procesem stopniowego doskonalenia, w ramach którego przedsiębiorstwo może coraz lepiej zarządzać relacjami z interesariuszami. Taką strategię należy traktować jak inwestycję, a nie wyłącznie jako koszt ponoszony przez przedsiębiorstwo.

\section{Literatura}

1. Bazzichi O., Społeczna odpowiedzialność przedsiębiorstwa [w:] Społeczeństwo, „Studia, prace badawcze, dokumenty z zakresu nauki społecznej Kościoła”, 55/56 (3/4)/2003.

2. Bąk M., Bednarz P., Kulawczuk P., Rataj R., Szczęśniak A., Zając P., Analiza korzyści ze stosowania zasad społecznej odpowiedzialności biznesu (CSR) w polskich przedsiębiorstwach. Streszczenie i wnioski, Fundacja „Instytut Badań nad Demokracją i Przedsiębiorstwem Prywatnym”, badanie dostępne na stronie fundacji: http://www.iped.pl/publikacje.php.

3. Co PR-owcy myśla o CSR? Raport z badania na temat postaw PR-owców wobec idei CSR, przeprowadzonego przez Forum Odpowiedzialnego Biznesu i Polskie Stowarzyszenie Public Relations [w:] Raport Odpowiedzialny biznes w Polsce w 2006 roku. Dobre praktyki, Forum Odpowiedzialnego Biznesu, Warszawa 2007.

4. Europejskie standardy etyki i społecznej odpowiedzialności biznesu, W. Gasparski (red.), 2003, Wydawnictwo Wyższej Szkoły Przedsiębiorczości i Zarządzania im. Leona Koźmińskiego, Warszawa.

5. Filek J., 2006, Społeczna odpowiedzialność biznesu, Urząd Ochrony Konkurencji i Konsumentów, Warszawa. 
6. Gryszka M., Etycznie znaczy skutecznie [w:] W. Gasparski (red.), 2002, Etyka biznesu w zastosowaniach praktycznych: inicjatywy, programy, kodeksy, Centrum Etyki Biznesu IFiS PAN \& WSPiZ oraz Biuro Stałego Koordynatora ONZ w Polsce, Warszawa.

7. Lewicka-Strzałecka A., Etyczne standardy firm i pracowników, Wydawnictwo IFiS PAN, Warszawa 1999.

8. Menedżerowie 500 i odpowiedzialny biznes: wiedza - postawy - praktyka, Raport Forum Odpowiedzialnego Biznesu opracowany we współpracy z Bankiem Światowym i Akademią Rozwoju Filantropii, Warszawa 2003.

9. Pierwsze w Polsce kompleksowe badanie na temat postaw konsumentów oraz liderów opinii wobec idei społecznej odpowiedzialności biznesu, Komunikowanie na rzecz CSR, czyli społecznej odpowiedzialności biznesu, Fundacja Komunikacji Społecznej, Warszawa 2003.

10. Rok B., 2004, Odpowiedzialny biznes w nieodpowiedzialnym świecie; Akademia Rozwoju Filantropi w Polsce, Forum Odpowiedzialnego Biznesu, Warszawa.

11. Sójka J.; Czy należy ukrywać strategiczny wymiar etyki? [w:] W. Gasparski (red.), 2003, Europejskie standardy etyki i społecznej odpowiedzialności biznesu, Wydawnictwo Wyższej Szkoły Przedsiębiorczości i Zarządzania im. Leona Koźmińskiego, Warszawa.

12. What Does Business Think about Corporate Social Responsibility? Part II: A Comparison of Attitudes and Practices in Hungary, Poland and Slovakia, Enabling a Better Environment for CSR in CEE Countries Project (publikacja elektroniczna).

13. Young S., 2005, Etyczny kapitalizm, METAmorfoza, Wrocław.

\section{Benefits from the Implementation of the Principles of Corporate Social Responsibility in a Company}

The corporate social responsibility - a completely new idea until quite recently - becomes more and more indispensable in the company strategy. It is so because nowadays CSR is associated with a series of benefits.

The paper presents the very idea of social responsibility of business company as well as the definition of stakeholders. It also shows profits from the using the CSR programs in a company. The last part of the paper presents results of the research that confirms CSR is not just a philanthropic activity but also a factor that brings benefits to the company and its local community. 